\title{
Sensory Evaluation of Snacks Produced From Wheat-Breadfruit Flour and Nutritional Composition of the Flour Blends
}

\author{
Folorunso, Adekunle A. ${ }^{\circledR}$ \\ Habeeb, Aisha S. ${ }^{2}$ \\ Ajayi, Odunola T. ${ }^{3}$
}

${ }^{1,3}$ Department of Family, Nutrition and Consumer Sciences, Faculty of Agriculture, Obafemi Awolowo University, Ile-Ife, Nigeria.

${ }^{2}$ Email:kunlefolly2@yahoo.com Tel: +2348038084579

${ }^{3}$ Email:odunavotitilayo@gmail.com Tel:+2347032680912

${ }^{2}$ Department of Hospitality Management, Federal Polytechnic, Bida, Niger State, Nigeria. sEmail:aishatuhabeeb600@gmail.com Tel:+2348036549975

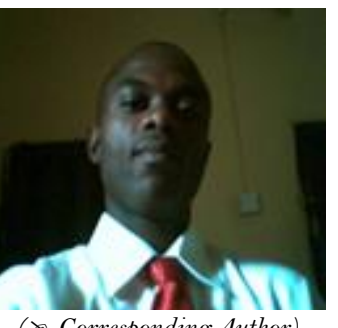

\section{Abstract}

This study investigated sensory nutritional evaluation of snacks produced from wheatbreadfruit flour blends. Two different snacks, meat pie and chin- chin were produced using three different mixing proportions (50:50,30:70 \& 70:30) of wheat-breadfruit flour blends for each making a total of six snack samples respectively. Fresh breadfruits, wheat flour and other ingredients were obtained from in Ile-Ife, Osun state. The samples were presented to a 50 member panelists to rate them on a 9-point hedonic scale and proximate analysis was also conducted on the flour blends using standard methods to determine their nutritional composition. Analysis of variance (ANOVA) was performed on the data gathered. The result showed that the highest value of moisture content, ash content and crude fiber content were observed in flour sample A (50:50), highest value of protein content, and fat content were observed in flour sample B (30:70) and highest value of carbohydrate content was observed in flour sample $\mathrm{C}(70: 30)$. Results revealed that there are significant difference at $(\mathrm{p}<0.05)$ in the protein, fat, crude fiber, and carbohydrate content of the blends of flour. There are significant difference at $(\mathrm{p}<0.05)$ in the results for sensory evaluation of chin chin and meat pie samples. The highest values for chin- chin samples are 7.60, 7.74, 7.76, 7.62, and 7.84 for colour, flavor, taste, texture and overall acceptance respectively. And for the meat pie samples, the highest values are 7.56, 7.42, 7.52, 7.54, and 7.68 for colour, flavor, taste, texture and overall acceptance respectively. It was concluded that snack samples produced from $30 \%$ breadfruit flour with $70 \%$ wheat flour blend are the most preferable by the panelists.

Keywords: Nutritional composition, Post-harvest loss, Imported wheat, Locally crops, Sensory analysis, Breadfruit.

Citation | Folorunso, Adekunle A. Habeeb, Aisha S.; Ajayi, Odunola T. (2019). Sensory Evaluation of Snacks Produced From Wheat-Breadfruit Flour and Nutritional Composition of the Flour Blends. Agriculture and Food Sciences Research, 6(1): 89-97. History:

Received: 19 February 2019

Revised: 25 March 2019

Accepted: 29 April 2019

Published: 4 July 2019

Licensed: This work is licensed under a Creative Commons Attribution 3.0 License (cc)

Publisher: Asian Online Journal Publishing Group
Contribution/Acknowledgement: All authors contributed to the conception and design of the study.

Funding: This study received no specific financial support.

Competing Interests: The authors declare that they have no conflict of interests.

Transparency: The authors confirm that the manuscript is an honest, accurate, and transparent account of the study was reported; that no vital features of the study have been omitted; and that any discrepancies from the features of the study have been omit

Ethical: This study follows all ethical practices during writing.

\section{Contents}

1. Introduction

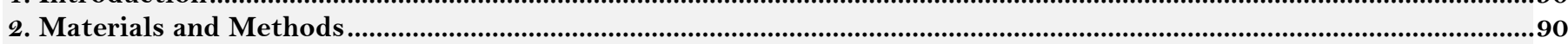

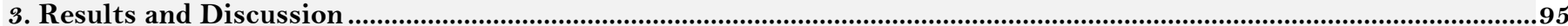

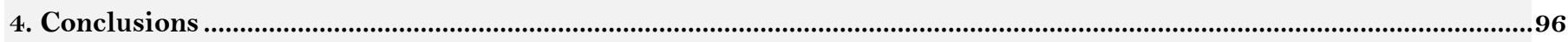

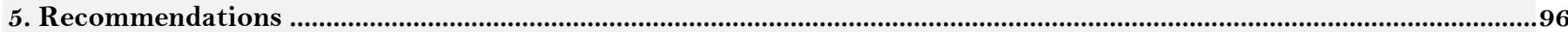

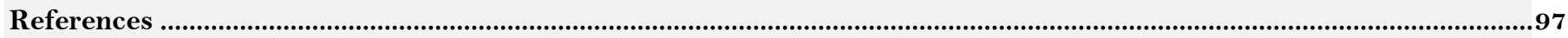




\section{Contribution of this paper to the literature}

This contributes to existing literature by examining the diversification of breadfruit, a locally grown crop in terms of nutritional composition and consumer acceptability using wheat-breadfruit flour blends in snacks production.

\section{Introduction}

Snacks are important foods which come in a variety of forms including packaged snack foods and other processed food as well as items made from fresh ingredients at home, the consumption of which is steady and increasing in Nigeria. It is a portion of food, smaller than a regular meal, generally eaten between meals. It has been hitherto produced from wheat as a major raw material. In Nigeria, wheat production is limited and wheat flour is imported to meet local flour needs for bakery products as such huge amount of hard earned foreign exchange is used every year for importation of wheat [1].

Efforts have been made to promote the use of composite flours in which flour from locally grown crops and high protein seeds replace a portion of wheat flour for use in snacks, thereby decreasing the demand for imported wheat and producing protein-enriched bread [2].

Breadfruit (Artocarpus altilis) is a member of the Moraceae family and is normally consumed after cooking. It's a rich source of carbohydrates, fiber, vitamin (vitamin C) and mineral (potassium). This plant plays a main function to ensure food safety in the rural communities where they are predominant due to its high carbohydrate content (76.71 to $79.24 \%$ ). It has been used as an important source of energy for years. In Africa, breadfruits are found in some country (Senegal, Guinea-Bissau, Cameroun, Sierra Leone, Nigeria, Liberia and Ghana). However, the current usage, particularly, in developing countries, is limited by the poor fresh fruit storage properties. A few days after harvesting (3 days), the deterioration of the fruit settles and because of their high water content they are easily susceptible to microbial attack as well as their bulky nature makes their transportation difficult. It is therefore reasonable to maximize the potential of this precious nutritious fruit by transforming them into various finished products easily storable.

This production of flour from breadfruit is a useful technique to extend its storage and consumption. Different conventional flours are important and have precious functional roles in global food systems. However, their increasing price led to the search of other flours less expensive unconventional as an alternative for replacement partially or completely the traditional conventional flours in foods as a means against malnutrition [3].

Many developing nations spend huge amount of their foreign exchange for the importation of food especially wheat, rice and sugar. For instance, in 2011 Africa spent more than \$50 billion on food imports. Nigeria spends $\$ 4.2$ billion yearly for the importation of wheat. According to Amusa, et al. [2] in 2010 alone, Nigeria spent 635 billion ( $\$ 4.2$ billion) on the importation of wheat, It has been reported that wheat importation is growing at the rate of $13 \%$ per annum. It has been estimated that at this growth rate, Nigeria wheat importation could reach 17 million metric tons (MMT) by 2020, which is equivalent to the entire wheat production by Canada (the third largest wheat producing country in the World [2].

The use of composite flours has been reported by many authors. Oloye [4] investigated the use of supplementation of flours of soybean and plantain in wheat in the production of bread. Also, Mepba, et al. [3] produced composite breads and biscuits from mixed flours of wheat and plantain, with $30 \%$ supplementation of plantain flour. Though breadfruit has been made into flour and evaluated in bakery products not much has been done in the area of composite flour blends of breadfruit and beniseed. Therefore, it becomes pertinent to evaluate the composite flours aiming at reducing wheat flour inflation and curtail excessive losses of breadfruit during season. Breadfruit is a valuable food resource, but its usage is limited by poor storage properties of the fresh fruit. Therefore, there is need for conversion into flour to provide a more stable storage form as well as increasing its versatility [5].

Hence, this study was aimed to determine the nutritional composition of wheat-breadfruit flour blends and assess the sensory qualities of snacks produced from wheat-breadfruit flour. The specific objectives of this study include:

i. To assess the nutritional properties of flour produced from wheat breadfruit flour blends

ii. Produce the flour blends of different proportions.

iii. Assess the sensory evaluation of products produced from wheat-breadfruit flour blends

The study will be of utmost importance to the catering establishments as the study will enlighten them on the benefit of making use of blend of wheat-breadfruit flour in snacks production. Also, it will help the government to minimize importation activities by reducing the quantity of wheat flour importation as the study ascertain the importance of blending wheat flour with breadfruit flour for snacks production.

\section{Materials and Methods}

\subsection{Collection of Materials}

Fresh breadfruit fruits were obtained at Gbongan, Osun State, while wheat flour and other ingredients were obtained from Lagere market in Ile-Ife, Osun state. The production of the snacks took place at Food Nutrition and Dietetics Laboratory in the department of Family, Nutrition and Consumer Science, Faculty of Agriculture, Obafemi Awolowo University. Knife.

Tools and equipment include Frying pan, Chopping board, Rolling pin, Bowl, Colander, Draining spoon and

\subsection{Production of Breadfruit into Flour}

The process for making the breadfruit flower is as follow; the breadfruit was washed and peeled. Then, it was halved and the heart was removed. The halves was then cut into very thin slices, then the slices were laid on drying rack in the sun to dry. Breadfruit must be brittle when properly dried. The dried breadfruit was 
grinded using attrition mill and was sieved several times until a powdery substance was formed. The breadfruit flour was then stored in clean air tight jars.

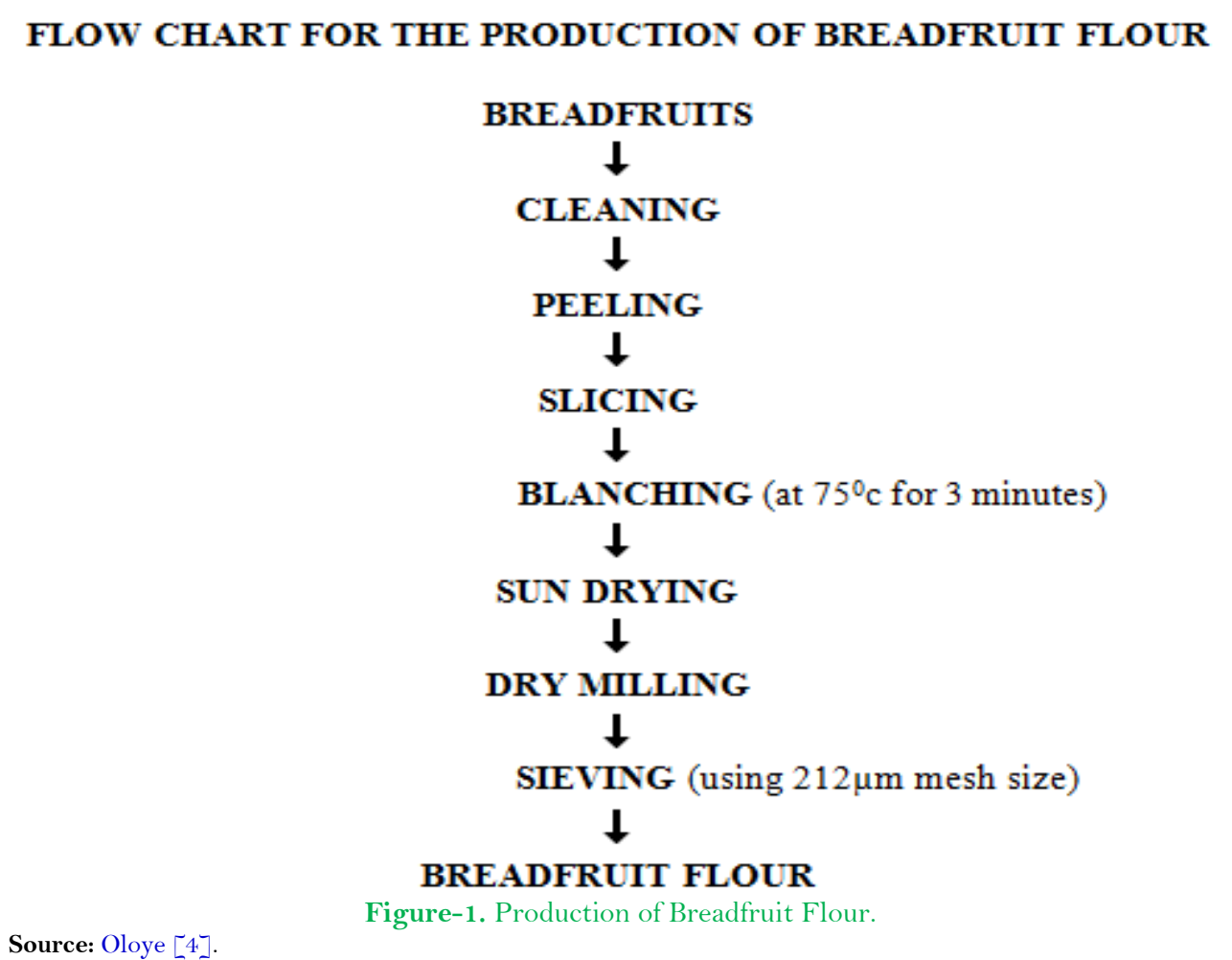

\subsection{Mixing Proportions}

\section{Sample 1 (Chin-Chin):}

A: $50 \%$ breadfruit flour with $50 \%$ wheat flour,

B: $30 \%$ breadfruit flour with $70 \%$ wheat flour,

C: $70 \%$ breadfruit flour with $30 \%$ wheat flour

\section{Sample 2 (Meat pie):}

A: $50 \%$ breadfruit flour with $50 \%$ wheat flour,

B: $30 \%$ breadfruit flour with $70 \%$ wheat flour,

C: $70 \%$ breadfruit flour with $30 \%$ wheat flour

\subsection{Nutritional Determination of the Blends}

Nutritional determination of the flour blends were carried out using methods of Association of Analytical Chemists [6].

\section{Moisture Content}

One gram of sample in pre- weighed crucible was placed in an oven $\left(105^{\circ} \mathrm{C}\right)$ for 24 hours, cooled, and reweighed. The percentage moisture was calculated as follows:

Moisture $(\%)=\frac{W_{2}-W_{3}}{W_{2}-W_{1}} X 100$

Where $\mathrm{W}_{1}$ is the weight of the crucible, W2 is the weight of the crucible after drying at $105^{\circ} \mathrm{C}$ and sample, and W3 is the weight of the crucible and the sample after cooling in airtight desiccators.

\section{Crude Protein}

Crude protein content was determined using the micro- Kjeldahl methods as prescribed by Pearson [7]. A volume of $10 \mathrm{ml} \mathrm{H}_{2} \mathrm{SO}_{4}$ added to $3 \mathrm{~g}$ of sample was digested with a Kjeldahl digestor (Model Bauch 4390) for one and half hour. A volume of $40 \mathrm{ml}$ water was added and distilled using a Kjeldahl distillation unit (Model unit B-316) containing 40\% concentrated sodium hydroxide and Millipore water. Liberated ammonia was collected in $20 \mathrm{ml}$ boric acid with bromocresol green and methyl red indicators and titrated against $0.04 \mathrm{~N} \mathrm{H}_{2} \mathrm{SO}_{4}$. A blank (without sample) was likewise prepared. Percent protein was calculated as:

Crude Protein (\%)

$=\frac{\text { Sample titer-blank Titer } \times 14 \times 6.25}{\text { Sample Weight }} \times 100$

Where 14 is the molecular weight of nitrogen and 6.25 is the nitrogen factor

Where 14 is the molecular weight of nitrogen and 6.25 is the nitrogen factor.

\section{Crude Fiber}

A weighed crucible containing $1 \mathrm{~g}$ of defatted sample was attached to the extraction unit (in Kjeldahl, D40599, Behr Labor-Technik GmbH, Düsseldorf, Germany) and into this $150 \mathrm{ml}$ of hot $1.25 \% \mathrm{H}_{2} \mathrm{SO}_{4}$ was added and digested for 30minutes,the acid was drained and sample washed with hot distilled water for $1 / 2$ hour. The crucible was removed and oven dried overnight at $105^{\circ} \mathrm{C}$, cooled, weighed and incinerated at $550^{\circ} \mathrm{C}$ in a muffle furnace ( MF- 1-02;PCSIR Labs, Lahore, Pakistan) overnight and reweighed after cooling. Percentage extracted fiber was calculated as:

Crude Fiber (\%)

$$
=\frac{\text { Weight of Digested Sample }- \text { Weight of ashed sample }}{\text { Weight of Sample }} X 100
$$




\section{Lipid}

Lipid content was estimated using TecatorSoxtec (Model 2043[20430001];Hilleroed, Denmark). A quantity of $1.5 \mathrm{~g}$ sample was mixed with $2.3 \mathrm{~g}$ anhydrous sulfate was weighed into a thimble and covered with absorbent cotton, while $40 \mathrm{ml}$ of petroleum ether $(40-60 \mathrm{c} \mathrm{Bpt})$ was added to a pre-weighed cup. Both thimble and cup were attached to the Extraction Unit. The sample was extracted using ethanol for 30min and rinsed for one and half hour. Thereafter, the solvent evaporated from the cup to the condensing column. Extracted fat in the cup was then placed in an oven at $105^{\circ} \mathrm{C}$ for 1 hour and cooled and weighed. Percent fat was calculated as:

$$
\text { Lipid }(\%)=\frac{\text { Initial cup weight }- \text { Finaql cup weight }}{\text { Weight of Sample }} \times 100
$$

Ash

Ash and mineral contents were determined according to AOAC (Association of Analytical Chemists) numbers 923.03 and 984.27 [6]. Two grams of sample was added into a pre-weighed crucible was incinerated in muffle furnace at $600^{\circ} \mathrm{C}$

$$
\operatorname{Ash}(\%)=\frac{W_{2}-W_{3}}{W_{2}-W_{1}} \times 100
$$

Where W1 is the weight of cleaned, dried, ignited, and cooled crucibleW2 the weight of the crucible and sample after incinerating at $600^{\circ} \mathrm{C}$, and W3 the weight of the crucible and sample after cooling in an airtight homogenized vessel.

\section{Carbohydrate}

The carbohydrate content was determined by difference, that is, addition of all the percentages of moisture, fat, crude protein, ash, and crude fiber was subtracted from $100 \%$. This gave the amount of nitrogen- free extract otherwise known as carbohydrate.

$\%$ carbohydrate $=100-(\%$ moisture $+\%$ Fat $+\%$ Ash $+\%$ Crude fiber $+\%$ Crude protein $)$

\section{Energy Value}

The sample energy value was estimated (In kcal/g) by multiplying the percentage of crude protein, crude lipid, and carbohydrate with the recommended factors (2.44, 8.3, and 3.57, respectively) as proposed by Martin and Coolidge [8].

\subsection{Production of Snacks}

Two snacks were produced with the blends of wheat-breadfruit flour at different proportions making a total of six snack samples:

1. Production of chin-chin with $50 \%$ breadfruit flour and $50 \%$ wheat flour Ingredients

(1) $100 \mathrm{~g}$ of breadfruit flour and $100 \mathrm{~g}$ of wheat flour

(2) 20ml evaporated milk (Peak Milk) / 20g powdered milk

(3) 100 granulated sugar

(4) $100 \mathrm{~g}$ margarine

(5) 1 medium nutmegs $1 / 2$ teaspoons ground nutmeg

(6) $200 \mathrm{ml}$ Vegetable Oil (tasteless and odourless)

The milk and sugar was mixed in a bowl and left to soak. In a separate bowl, the ground nutmeg was mixed with $200 \mathrm{~g}$ of composite flour, then the margarine was rubbed into the flour till well mixed with the flour, leaving no lumps. The sugar/milk mixture was then added to the margarine/flour mixture and was mixed by hand till smooth dough was achieved. The dough was then placed on the chopping board and was kneaded gently with a dough roller. Then the dough was cut into desire size flat. Then, the dough was deep fried in hot vegetable oil till when a golden brown colour was obtained. The fried pieces were set onto a flat tray to dry and cool down quickly. When the chin- chin had cooled down completely, it was stored in a dry, airtight container.

2. Production of chin -chin with $30 \%$ breadfruit flour and $70 \%$ wheat flour Ingredients

(1) $60 \mathrm{~g}$ of breadfruit flour and $140 \mathrm{~g}$ of wheat flour

(2) 20ml evaporated milk (Peak Milk) / 20g powdered milk

(3) 100 granulated sugar

(4) $100 \mathrm{~g}$ margarine

(5) 1 medium nutmegs $1 / 2$ teaspoons ground nutmeg

(6) $200 \mathrm{ml}$ Vegetable Oil (tasteless and odorless)

The milk and sugar were mixed in a bowl and left to soak. In a separate bowl, the ground nutmeg was mixed with $60 \mathrm{~g}$ of breadfruit flour and $140 \mathrm{~g}$ of wheat flour, then the margarine was rubbed into the flour till well mixed with the flour, leaving no lumps. The sugar/milk mixture was added to the margarine/flour mixture and was mixed by hand till smooth dough was achieved. The dough was then placed on the chopping board and was kneaded gently with a dough roller. Then the dough was cut into desire size flat. Then, the dough was deep fried in hot vegetable oil till when a golden brown colour was obtained. The fried pieces were set onto a flat tray to dry and cool down quickly. When the chin- chin had cooled down completely, it was stored in a dry, airtight container.

3. Production of chin- chins with $70 \%$ breadfruit flour and $30 \%$ wheat flour Ingredients

(1) $140 \mathrm{~g}$ of breadfruit flour and $60 \mathrm{~g}$ of wheat flour

(2) 20ml evaporated milk (Peak Milk) / 20g powdered milk

(3) 100 granulated sugar

(4) $100 \mathrm{~g}$ margarine

(5) 1 medium nutmegs $1 / 2$ teaspoons ground nutmeg 
(6) 200ml Vegetable Oil (tasteless and odourless)

The milk and sugar was mixed in a bowl and left to soak. In a separate bowl, the ground nutmeg was mixed with $140 \mathrm{~g}$ of breadfruit flour and $60 \mathrm{~g}$ of wheat flour, then the margarine was rubbed into the flour till well mixed with the flour, leaving no lumps. The sugar/milk mixture was then added to the margarine/flour mixture and was mixed by hand till smooth dough was achieved. The dough was then placed on the chopping board and was kneaded gently with a dough roller. Then the dough was cut into desire size flat. Then, the dough was deep fried in hot vegetable oil till when a golden brown colour was obtained. The fried pieces were set onto a flat tray to dry and cool down quickly. When the chin chin had cooled down completely, it was stored in a dry, airtight container.

4. Production of meat- pie with $50 \%$ breadfruit flour and $50 \%$ wheat flour Ingredients

(1) $100 \mathrm{~g}$ of breadfruit flour and $100 \mathrm{~g}$ of wheat flour

(1) Irish potatoes

(2) $200 \mathrm{~g}$ Minced beef

(3) 1 medium onion

(4) 1 teaspoon baking powder

(5) Carrot

(6) 2 medium eggs

(7) $100 g$ margarine

$100 \mathrm{~g}$ of breadfruit flour and $100 \mathrm{~g}$ of wheat flour was sifted into a bowl, then baking powder was added and mixed with the flour. The margarine was then added and mixed with the dough until a crumb like texture is formed. Then small amount of water was added. The dough was then kneaded thoroughly. Onion and irish potatoes was chopped and was fried together with the minced beef in vegetable oil and appropriate seasoning was added. The rolling pin was used to flatten the dough and was cut into required sizes. Then the fillings were filled inside the pie and the edges of the dough enclosed by applying egg while on the edges to prevent the filling from coming out of the dough during baking. The pie was then baked at $70^{\circ} \mathrm{c}$ for 30 minutes till a golden brown colour was obtained.

5. Production of meat -pie with $30 \%$ breadfruit flour and $70 \%$ wheat flour Ingredients

1) $60 \mathrm{~g}$ of breadfruit flour and $140 \mathrm{~g}$ of wheat flour

2) Irish potatoes

3) $200 \mathrm{~g}$ Minced beef

4) 1 medium onion

5) 1 teaspoon baking powder

6) Carrot

7) 2 medium eggs

8) $100 \mathrm{~g}$ margarine

$60 \mathrm{~g}$ of breadfruit flour and $140 \mathrm{~g}$ of wheat flour was sifted into a bowl, then baking powder, was added and mixed with the flour. The margarine was then added and mixed with the dough until a crumb like texture is formed. Then small amount of water was added. The dough was then kneaded thoroughly. Onion and irish potatoes was chopped and was fried together with the minced beef in vegetable oil and appropriate seasoning was added. The rolling pin was used to flatten the dough and was cut into required sizes. Then the fillings were filled inside the pie and the edges of the dough enclosed by applying egg while on the edges to prevent the filling from coming out of the dough during baking. The pie was then baked at $70^{\circ} \mathrm{c}$ for 30 minutes till a golden brown colour was obtained.

6. Production of meat pie with 70\% breadfruit flour and $30 \%$ wheat flour Ingredients

9) $140 \mathrm{~g}$ of breadfruit flour and $60 \mathrm{~g}$ of wheat flour

10) Irish potatoes

11) $200 \mathrm{~g}$ Minced beef

12) 1 medium onion

13) 1 teaspoon baking powder

14) Carrot

15) 2 medium eggs

16) $100 \mathrm{~g}$ margarine

$140 \mathrm{~g}$ of breadfruit flour and $60 \mathrm{~g}$ of wheat flour was sifted into a bowl, then baking powder, was added and mixed with the flour. The margarine was then added and mixed with the dough until a crumb like texture is formed. Then small amount of water was added. The dough was then kneaded thoroughly. Onion and irish potatoes was chopped and was fried together with the minced beef in vegetable oil and appropriate seasoning was added. The rolling pin was used to flatten the dough and was cut into required sizes. Then the fillings were filled inside the pie and the edges of the dough enclosed by applying egg while on the edges to prevent the filling from coming out of the dough during baking. The pie was then baked at $70^{\circ} \mathrm{C}$ for 30 minutes till a golden brown colour was obtained. 

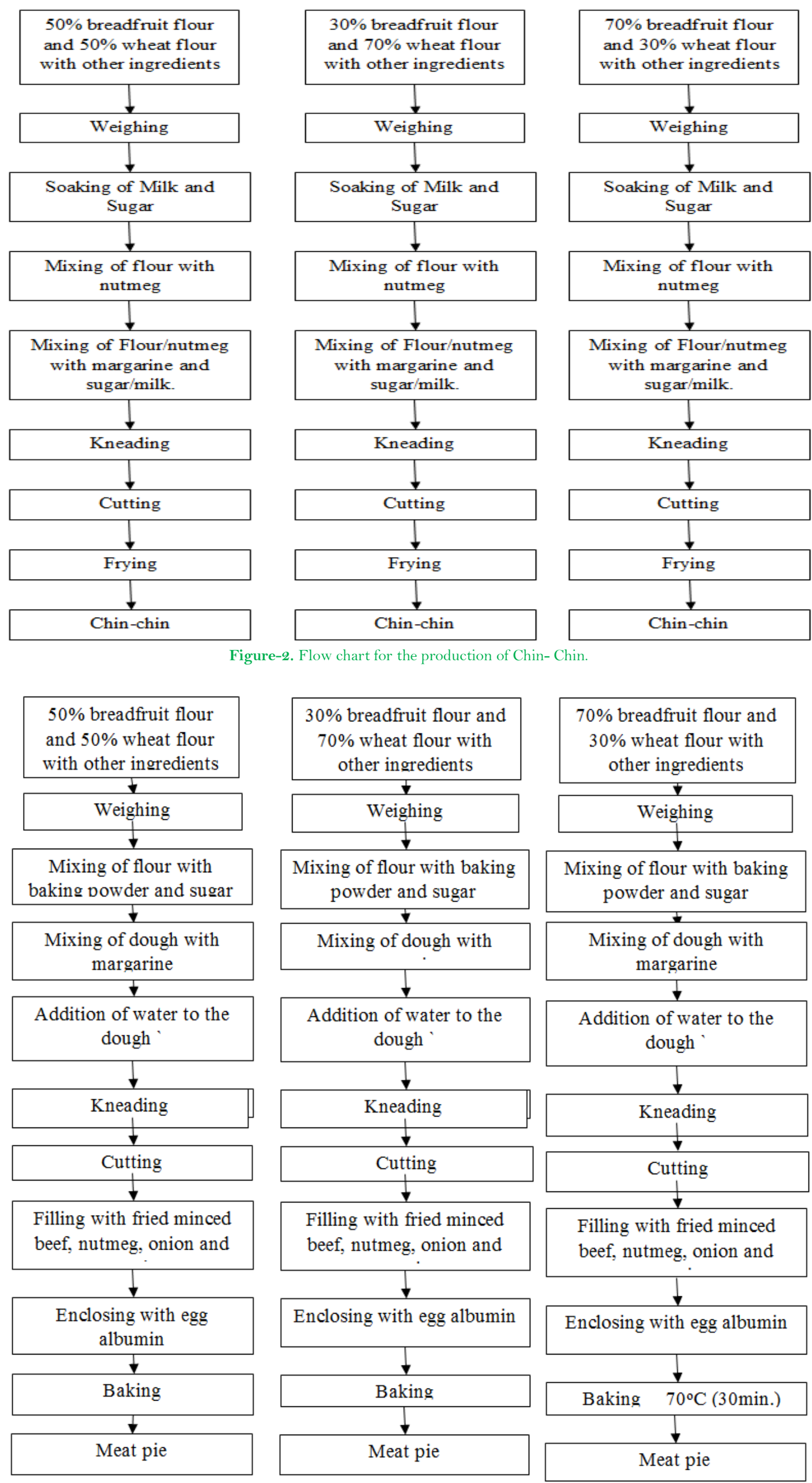

Filling with fried minced

beef, nutmeg, onion and

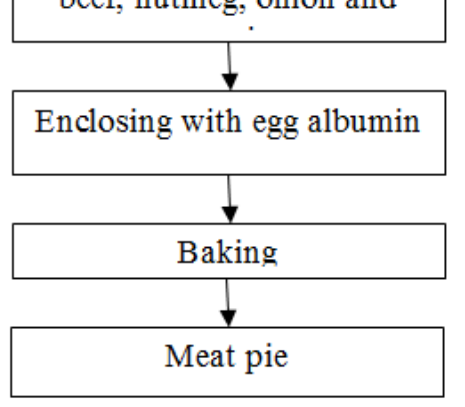

Filling with fried minced

beef, nutmeg, onion and

Figure-3. Flow chart for the production of Meat pie.

\subsection{Sensory Analysis Test}

The two different snacks were made using three different mixing proportions (A, B and C) for each snack to make a total of 6 snack samples were evaluated using a 9-point hedonic scale. The samples were presented to a 50 - member panelist to rate them on the hedonic scale where 9 was maximum and 1 was minimum. The samples were scored for the appearance, colour, taste, flavor and overall acceptability. The panelists were instructed to rinse their mouth thoroughly with water after testing any of the samples before proceeding to the next sample. This is to prevent the taste of the samples from interfering with one another. 


\subsection{Statistical Analysis}

Analysis of Variance (ANOVA|) was performed on the data gathered from the sensory evaluation to determine differences between the samples.

\section{Results and Discussion}

\subsection{Sensory Evaluation}

Table 1 summarizes the sensory mean scores for colour, flavour, taste, texture, overall acceptance for snack sample 1 and sample 2 respectively.

\section{Snack Sample 1:}

A: $50 \%$ breadfruit flour with $50 \%$ wheat flour,

B: $30 \%$ breadfruit flour with $70 \%$ wheat flour,

C: $70 \%$ breadfruit flour with $30 \%$ wheat flour

\section{Snack Sample 2:}

D: $50 \%$ breadfruit flour with $50 \%$ wheat flour,

E: $30 \%$ breadfruit flour with $70 \%$ wheat flour,

F: $70 \%$ breadfruit flour with $30 \%$ wheat flour

The snack sample B was rated highest $(7.56 \pm 1.15)$ in terms of colour followed by snack sample A with (7.48 \pm 0.10$)$ and sample $\mathrm{C}(7.00 \pm 1.54)$ was rated least out of the three chin chin samples. The snack sample E

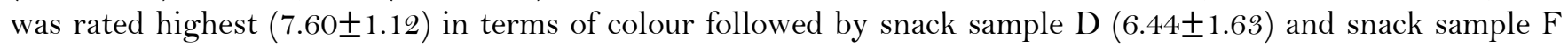
$(6.12 \pm 1.76)$ was rated least out of the three meat pie samples. The snack sample B was rated highest $(7.42 \pm 1.18)$ in terms of flavor followed by snack sample A $(6.88 \pm 1.55)$ and snack sample C $(6.48 \pm 1.71)$ was rated least out of the three chin chin samples. The snack sample $\mathrm{E}$ was rated highest (7.74 \pm 1.26$)$ in terms of flavor followed by snack sample D (6.06 \pm 1.85$)$ and snack sample $(5.64 \pm 2.09)$ was rated least out of the three meat pie samples. The snack sample B was rated highest (7.52 \pm 1.36$)$ in terms of taste followed by snack sample $\mathrm{A}(6.82 \pm 1.72)$ and snack sample $\mathrm{C}(6.48 \pm 1.91)$ was rated least out of the three chin chin samples.

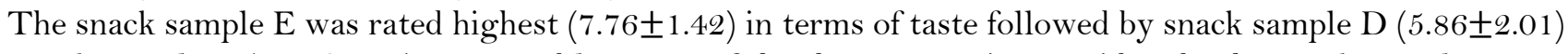
and snack sample $\mathrm{F}(5.54 \pm 2.22)$ was rated least out of the three meat pies considered. The snack sample B was rated highest $(7.54 \pm 1.01)$ in terms of texture followed by snack sample A $(7.36 \pm 1.14)$ and snack sample C $(6.00 \pm 1.83)$ was rated least out of the three chin chin samples. The snack sample $\mathrm{E}$ was rated highest $(7.62 \pm 1.37)$ in terms of texture followed by snack sample D $(6.16 \pm 1.74)$ and snack sample $\mathrm{F}(5.70 \pm 1.88)$ was rated least out of the three meat pies samples. The snack sample B was rated highest (7.68 \pm 1.44$)$ in terms of

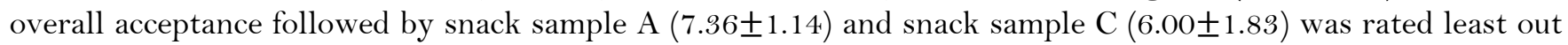
of the three chin chin samples. The snack sample $\mathrm{E}$ was rated highest $(7.84 \pm 1.28)$ in terms of overall acceptance followed by snack sample D $(6.30 \pm 1.69)$ and snack sample $\mathrm{F}(5.88 \pm 1.80)$ was rated least out of the three meat pies samples.

Table-1. Sensory evaluation of snacks from blends of breadfruit flour and wheat flour...

\begin{tabular}{l|c|c|c|c|c|c}
\hline & \multicolumn{3}{|c|}{ Chin -Chin } & \multicolumn{3}{c}{ Meat pie } \\
\hline Parameter & A & B & C & D & E & F \\
\hline Colour & $6.44 \pm 1.63^{\mathrm{b}}$ & $7.60 \pm 1.12^{\mathrm{a}}$ & $6.12 \pm 1.76^{\mathrm{c}}$ & $7.48 \pm 0.10^{\mathrm{b}}$ & $7.56 \pm 1.15^{\mathrm{a}}$ & $7.00 \pm 1.20^{\mathrm{c}}$ \\
\hline Flavour & $6.06 \pm 1.85^{\mathrm{b}}$ & $7.74 \pm 1.26^{\mathrm{a}}$ & $5.64 \pm 2.09^{\mathrm{c}}$ & $6.88 \pm 1.55^{\mathrm{b}}$ & $7.42 \pm 1.18^{\mathrm{a}}$ & $6.48 \pm 1.71^{\mathrm{c}}$ \\
\hline Taste & $5.86 \pm 2.01^{\mathrm{b}}$ & $7.76 \pm 1.42^{\mathrm{a}}$ & $5.54 \pm 2.22^{\mathrm{c}}$ & $6.82 \pm 1.72^{\mathrm{b}}$ & $7.52 \pm 1.36^{\mathrm{a}}$ & $6.48 \pm 1.91^{\mathrm{c}}$ \\
\hline Texture & $6.16 \pm 1.74^{\mathrm{b}}$ & $7.62 \pm 1.37^{\mathrm{a}}$ & $5.70 \pm 1.88^{\mathrm{c}}$ & $7.36 \pm 1.14^{\mathrm{b}}$ & $7.54 \pm 1.01^{\mathrm{a}}$ & $6.00 \pm 1.83^{\mathrm{c}}$ \\
\hline Overall acceptance & $6.30 \pm 1.69^{\mathrm{b}}$ & $7.84 \pm 1.28^{\mathrm{a}}$ & $5.88 \pm 1.80^{\mathrm{c}}$ & $7.24 \pm 1.19^{\mathrm{b}}$ & $7.68 \pm 1.44^{\mathrm{a}}$ & $6.60 \pm 1.83^{\mathrm{c}}$ \\
\hline Note: Fifferent superscript in the same column indicates significant difference $(p<0.05)$ & & \\
* Mean of standard deviation of fifty panelists (n=3) \\
Key: A: 50\% Breadfruit flour with 50\% Wheat flour Chin- Chin \\
B: 30\% Breadfruit flour with 70\% Wheat flour Chin -Chin \\
C:70\% Breadfruit flour with 30\% Wheat flour Chin -Chin \\
D: $50 \%$ Breadfruit flour with 50\% Wheat flour Meat pie \\
E:30\% Breadfruit flour with 70\% Wheat flour Meat pie \\
F: $70 \%$ Breadfruit flour with 30\% Wheat flour Meat pie
\end{tabular}

According to Table 1, there is significant difference in the colour, flavour, taste, texture and overall acceptance at $(\mathrm{P}<0.05)$ of snacks $\mathrm{A}$ and $\mathrm{B}, \mathrm{A}$ and $\mathrm{C}, \mathrm{B}$ and $\mathrm{C}$ respectively. Also, there is significant difference in the colour, flavour, taste, texture and overall acceptance at $(\mathrm{P}<0.05)$ of snacks $\mathrm{D}$ and $\mathrm{E}, \mathrm{D}$ and $\mathrm{F}, \mathrm{E}$ and $\mathrm{F}$ respectively. Snack B was rank highest in the colour, flavour, taste, texture and overall acceptance out of all the three chin- chin samples, thereby making it to be the most preferable by the panelists and snack $\mathrm{E}$ was rank highest in the colour, flavour, taste, texture and overall acceptance out of all the three meat pie samples, thereby making it to be the most preferable by the panelists, snack $\mathrm{C}$ of the chin -chin sample was ranked lowest in term of colour, flavour, taste, texture and overall acceptable and snack $\mathrm{F}$ of the meat pie samples was ranked lowest in term of colour, flavour, taste, texture and overall acceptable.

Based on the above illustrations, it can be concluded that there is significant difference in the colour, taste, flavour, texture and overall acceptance of all the snacks and that snack B is the most preferable sample from the chin- chin samples and snack $\mathrm{E}$ is the most preferable sample from the meat pie samples by the panelists while snack $\mathrm{C}$ and $\mathrm{F}$ is the least preferable by the panelists from the chin- chin and meat pie samples respectively. 


\subsection{Proximate Analysis}

Table 2 summarizes the proximate composition scores for protein, moisture content, fat, ash, crude, CHO and dry matter of wheat-breadfruit flour blends.

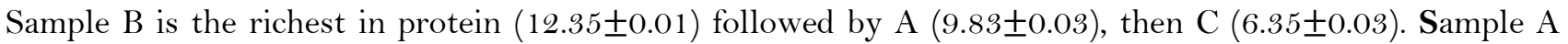

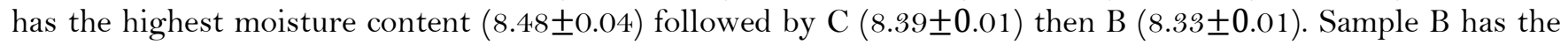
highest fat content $(1.77 \pm 0.01)$ followed by A $(1.21 \pm 0.0)$ then $\mathrm{C}(0.90 \pm 0.00)$. Sample A has the highest ash content (3.38 \pm 0.02$)$ followed by B (3.28 \pm 0.00$)$ then $\mathrm{C}(3.21 \pm 0.01)$. Sample A has the highest crude fiber content (2.63 \pm 0.01$)$ followed by B $(2.26 \pm 0.02)$ then $\mathrm{C}(1.78 \pm 0.02)$. Sample $\mathrm{C}$ is the richest in carbohydrate $(79.37 \pm 0.05)$

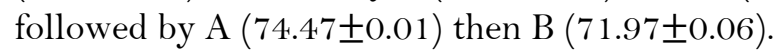

Sample C has the highest dry matter $(91.61 \pm 0.01)$ followed by B $(91.67 \pm 0.0)$ then A $(91.52 \pm 0.04)$.

Table-2. Proximate composition of blends of breadfruit flour and wheat flour.

\begin{tabular}{c|c|c|c}
\hline Nutrient & A & B & C \\
\hline Protein & $9.83 \pm 0.03^{\mathrm{b}}$ & $12.35 \pm 0.01^{\mathrm{a}}$ & $6.35 \pm 0.03^{\mathrm{c}}$ \\
\hline Moisture content & $8.48 \pm 0.04^{\mathrm{a}}$ & $8.33 \pm 0.01^{\mathrm{a}}$ & $8.39 \pm 0.01^{\mathrm{a}}$ \\
\hline Fat & $1.21 \pm 0.01^{\mathrm{b}}$ & $1.77 \pm 0.01^{\mathrm{a}}$ & $0.90 \pm 0.00^{\mathrm{c}}$ \\
\hline Ash & $3.38 \pm 0.02^{\mathrm{a}}$ & $3.28 \pm 0.00^{\mathrm{a}}$ & $3.21 \pm 0.01^{\mathrm{a}}$ \\
\hline Crude fiber & $2.63 \pm 0.01^{\mathrm{a}}$ & $2.26 \pm 0.02^{\mathrm{b}}$ & $1.78 \pm 0.02^{\mathrm{c}}$ \\
\hline CHO & $74.47 \pm 0.01^{\mathrm{b}}$ & $71.97 \pm 0.06^{\mathrm{c}}$ & $79.37 \pm 0.05^{\mathrm{a}}$ \\
\hline Dry matter & $91.52 \pm 0.04^{\mathrm{a}}$ & $91.67 \pm 0.01^{\mathrm{a}}$ & $91.61 \pm 0.01^{\mathrm{a}}$ \\
\hline
\end{tabular}

Note: *Different superscript in the same column indicates significant difference $(\mathrm{P}<0.05)$

* Mean of standard deviation of three determinations $(n=3)$

Key:

A: $50 \%$ Breadfruit flour with $50 \%$ Wheat flour

B: $30 \%$ Breadfruit flour with $70 \%$ Wheat flour

C: $70 \%$ Breadfruit flour with $30 \%$ Wheat flour

From Table 2 there is significant difference at $(\mathrm{P}<0.05)$ in the protein, fat, Crude fiber, and $\mathrm{CHO}$ of the flour samples and there is no significant difference at $(\mathrm{P}>0.05)$ in the moisture content, ash content and dry matter of the flour samples. The flour sample A has the highest moisture content, ash content and crude fiber content while flour sample B has the highest protein content, fat content and dry matter content and sample $\mathrm{C}$ has the highest carbohydrate content. Flour sample A has the lowest dry matter content, while flour sample B has the lowest carbohydrate and moisture content and sample $\mathrm{C}$ has the lowest protein, fat, ash and crude fiber content.

\subsection{Discussion}

The results for proximate composition of flours from blends of breadfruit flour and wheat flour of different proportions showed that there was significant difference at $(\mathrm{P}<0.05)$ in the protein, fat, Crude fiber, and carbohydrate content. The result showed that values ranging from 6.35 to $12.35 \%, 8.33$ to $8.48 \%$, 0.90 to $1.77 \%$, 3.21 to $3.38 \%, 1.78$ to $2.63 \%, 71.97$ to $79.37 \%, 91.52$ to $91.67 \%$ for protein, moisture content, fat, ash, crude fiber, carbohydrate and dry matter respectively. The result showed that the highest value moisture content, ash content and crude fiber content were observed in flour sample A while highest value of protein content, fat content and dry matter content were observed in flour sample B. Also, highest value of carbohydrate content was observed in flour sample $\mathrm{C}$. The lowest value of dry matter content was observed in flour sample A while the lowest value of carbohydrate and moisture content were observed in flour sample B and the lowest value of protein, fat, ash and crude fiber content were observed in flour sample $\mathrm{C}$. These results are in line with similar study on nutritional contents of processed local food flours by Isong [9]. The data reviewed that the protein contents for the samples were higher than the protein content (5.4\%) of maize biscuit reported by Adeyeye and Akingbala [10].

Also, there were significantly different $(\mathrm{p}<0.05)$ in the results for sensory evaluation of both chin chin and meat pie samples with values ranging from 6.12 to $7.60,5.64$ to $7.74,5.54$ to $7.76,5.70$ to $7.62,5.88$ to 7.84 for color, flavor, taste, texture and overall acceptance respectively of the chin- chin samples and from 7.00 to 7.56, 6.48 to $7.42,6.48$ to $7.52,6.00$ to $7.54,6.60$ to 7.68 for color, flavor, taste, texture and overall acceptance respectively of the meat pie samples. The highest value of color, flavor, taste, texture and overall acceptance was observed in snack B for the chin-chin and snack E for the meat pie sample, thereby making snacks with formulation of $30 \%$ breadfruit flour with $70 \%$ wheat flour to be the most preferable by the panelists. The result showed that all the sensory parameters of the snacks samples were all acceptable by the panelists.

\section{Conclusions}

The study showed that all sensory attributes of snacks produced from the various formulations comprising of blend of breadfruit flour and wheat flour were acceptable by the panelists with sample B from the chin- chin samples and sample E from the meat pie samples containing 30\% Breadfruit flour with $70 \%$ wheat flour having the highest overall acceptance by the panelists. The study also showed that flour sample B (30\% Breadfruit flour with $70 \%$ wheat flour) had higher nutritional contents in terms of protein, fat and dry matter content followed by flour sample A in terms of moisture content, Ash and crude fiber then flour sample C in term of carbohydrate content. In conclusion, sample B could be very suitable for the production of chin-chin and and sample E could be very suitable for the production of meat pie due to the dominance of the samples in both nutritional and sensory qualities over other samples.

\section{Recommendations}

It is therefore recommended that the production of snacks by mixing breadfruit flour with wheat flour using the right mixing proportion should be encouraged for the nutritional benefit of consumers. Increase in the 
proportion of Breadfruit flour from $30 \%$ to $40 \%$ and a decrease in the proportion of wheat flour from $70 \%$ to $60 \%$ in the production of snacks can also help to increase the nutritional and quality factors of the snacks by improving the carbohydrate content. From this study, in accordance with the results gotten from the analyses, the best blend that could be recommended for the consumers is $30 \%$ Breadfruit flour with $70 \%$ wheat flour due to its high nutritional factors. Also, sample A and D which is a blend of $50 \%$ Breadfruit flour with $50 \%$ wheat flour could also be recommended for making snacks due to its high carbohydrate content but consumers need to be enlightened on its richness in carbohydrate in order to enhance the level of acceptance of the snack.

\section{References}

[1] O. Olaoye, A. Onilude, and O. Idowu, "Quality characteristics of bread produced from composite flours of wheat, plantain and soybeans," African Journal of Biotechnology, vol. 5, pp. 1102-1 106, 2006.

[2] N. Amusa, I. Kehinde, and O. Ashaye, "Bio-deterioration of breadfruit (Artocarpus communis) in storage and its effects on the nutrient composition," African Journal of Biotechnology, vol. 1, pp. 57-60, 2002. Available at: https://doi.org/10.5897/ajb2002.000-010.

[3] H. D. Mepba, L. Eboh, and S. Nwaojigwa, "Chemical composition, functional and baking properties of wheat-plantain composite flours," African Journal of Food Nutrition Developmen, vol. 7, pp. 1-22, 2007.

[4] O. A. Oloye, "Sensory evaluation of and acceptance of composite bread from wheat, cassava starch and cassava flour blends," Unpublished PhD Thesis in Food Science and Technology Department, Federal University of Technology, Akure, 2006.

[5] A. J. Ajani, B. A. Osundahunsi, M. O. Akinsola, S. A. Arowora, E. A. Abiodun, and F. A. Pessu, "Chemical a nalysis of breadfruit (Artocarpus communis forst) from Southern Western Nigeria," Journal of Food Technology, vol. 1, pp. 29 - 35, 2012.

[6] AOAC, Official method of analysis: Association of official of analytical chemists. Gaithersburg, Maryland, USA: International (18 Ed), 2005 .

S. O. Pearson, Food analysis: Food science text series New York: Springer, 2010.

[8] E. A. Martin and A. A. Coolidge, Nutrition in action, 4th ed. New York: Holt, R and Wilson Co, 1978.

[9] N. C. Isong, "Processing and preservation of Nigerian fruits and green vegetable," in Proceedings of the Launching and First Annual Conference of Nigeria Institute of Food Science and Technology, 1977, pp. 49-55.

[10] S. A. Adeyeye and J. O. Akingbala, "Evaluation of nutritional and sensory properties of cookies produced from sweet potatomaize flour blends," Researcher, vol. 6, pp. 9-19, 2014. 